DOI: http://dx.doi.org/10.33846/hn31102

http://heanoti.com/index.php/hn

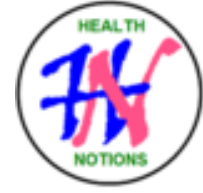

RESEARCH

URL of this article: http://heanoti.com/index.php/hn/article/view/hn31102

\title{
Type of Dominant Personality in Coronary Artery Heart Disease Patients
}

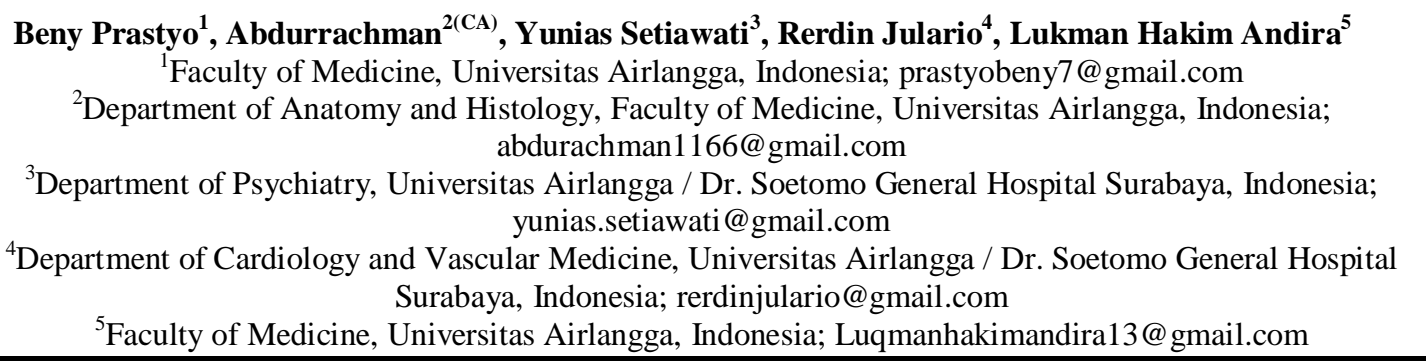

\begin{abstract}
Coronary heart disease is one of the leading causes of death in Indonesia. Personality is one of the risk factors of coronary heart disease. The aim of the study was to investigate the dominant personality according to Big Five Personality in patients with coronary heart disease. We used an analytical descriptive study with crosssectional design. The samples taken were patients with coronary heart disease in Dr. Soetomo General Hospital Surabaya in May 2019. Data of personality were collected using the Big Five Personality questionnaire. The result showed that the dominant personality according to Big Five Personality in patients with coronary heart disease was conscientiousness.
\end{abstract}

Keywords: big five personality; coronary heart disease; personality type

\section{INTRODUCTION}

\section{Background}

Cardiovascular disease is one of the causes of many deaths and disabilities throughout the world today. 17.9 million people or around $31 \%$ of global deaths are caused by cardiovascular disease ${ }^{(1)}$. One of the cardiovascular diseases with a high incidence of mortality rate globally is coronary heart disease. In Indonesia, coronary heart disease accounted for $24.6 \%$ of total deaths and was a leading cause in the cardiovascular disease group. In 2014, the prevalence of coronary heart disease in East Java in 2013 based on the doctor's diagnosis was $0.5 \%$ or around 144,279 patients and was the highest number of coronary heart disease sufferers $^{(2)}$.

Coronary heart disease is a disorder of heart function where there is a lack of blood supply in the heart muscle due to the narrowing of coronary arteries. Narrowing of the inner endothelial wall in one or more coronary arteries that occurs due to chronic accumulation of atheromatous plaque, which reduces blood flow rich in nutrients and oxygen that damage the structure and function of the heart ${ }^{(3)}$.

Epidemiological studies show that some risk factors that can increase a person's risk of coronary heart disease include age, family history, obesity, hyperlipidemia, smoking, diabetes mellitus, sex, race, history of hypertension, and stress ${ }^{(4)}$. The relationship between stress and disease is affected by the nature, number, and persistence of the stressors as well as by the individual's biological vulnerability (i.e., genetics, constitutional factors), psychosocial resources, and learned patterns of coping ${ }^{(5)}$. Stress also can not be separated from one's personality type. Personality not only affects the appraisal of and coping with stress, but it is also crucial with regard to the selection and shaping of stressful situations ${ }^{(6)}$. 
The personality can be described as someone's characteristics of thinking, feeling, and attitude, which is influenced by desire and cognition. According to Lewis Goldberg, personality is divided into five traits, Openness to Experience, Conscientiousness, Extraversion, Agreeableness, Neuroticism, known as The Big Five Personality Traits ${ }^{(7)}$.

Research that discusses the dominant personality types in people with coronary heart disease should be deepened, especially in Indonesia. This study aimed to determine the dominant personality type in a person based on The Big Five Personality Traits that diagnosed with coronary heart disease. So, through this study, We hope that preventive efforts can be found in new and more effective ways that focus on interventions on personality factors to help reduce the incidence of coronary heart disease in Indonesia.

\section{Purpose}

The purpose of this study is to describe the most dominant personality type of coronary heart disease outpatients in Outpatient Dr Soetomo General Hospital Surabaya May 2019.

\section{METHODS}

This study was a quantitative descriptive design and was carried out at the Cardiology Clinic of Dr. Soetomo General Hospital Surabaya in May 2019. This study used The Big Five Personality Traits questionnaire as a data collection tool. These questionnaires obtained data about the personality types of people with coronary heart disease in the Cardiology outpatient clinic at Dr Soetomo General Hospital Surabaya. This study was approved by the Research Ethics Committee of Dr. Soetomo General Hospital Surabaya with ethical clearance number of 1175/KEPK/V/2019.

\section{RESULT}

Table 1. Characteristics patients in Cardiac Polyclinic, Dr. Soetomo General Hospital, May 2019

\begin{tabular}{|c|c|c|c|c|c|}
\hline & \multicolumn{5}{|c|}{ Personality type according to The Big Five } \\
\hline & Conscientiousness & Neuroticsm & Agreeableness & Openness & Extraversion \\
\hline & (n) & (n) & (n) & (n) & (n) \\
\hline Total patients with CHD & 50 & 22 & 20 & 6 & 2 \\
\hline \multicolumn{6}{|l|}{ Sex } \\
\hline Male $(n=74)$ & 37 & 13 & 16 & 6 & 2 \\
\hline Female $(n=26)$ & 13 & 9 & 4 & 0 & 0 \\
\hline \multicolumn{6}{|l|}{ Age } \\
\hline Young adult (26-35) & 0 & 2 & 0 & 0 & 0 \\
\hline Late adult (36-45) & 4 & 3 & 1 & 0 & 0 \\
\hline Early elderly (46-55) & 15 & 5 & 5 & 2 & 0 \\
\hline Late elderly (56-65) & 12 & 7 & 6 & 2 & 1 \\
\hline Senior $(>65)$ & 19 & 5 & 8 & 2 & 1 \\
\hline
\end{tabular}

From the data, we obtained a sample of 100 patients with coronary heart disease (CHD). From all patient data collected, the majority of the patients characteristic is dominated by Male. The division of data, according to the patient's age, uses an adult age classification based on the Ministry of Health (MOH) of the Republic of Indonesia is dominated by seniors. 
Table 2. Patient's sex and age

\begin{tabular}{cccccc}
\hline & \multicolumn{5}{c}{ Age Category } \\
\cline { 2 - 6 } & $\begin{array}{c}\text { Young adult } \\
(26-35)\end{array}$ & $\begin{array}{c}\text { Late Adult } \\
(36-45)\end{array}$ & $\begin{array}{c}\text { Early elderly } \\
(46-55)\end{array}$ & $\begin{array}{c}\text { Late elderly } \\
(56-65)\end{array}$ & $\begin{array}{c}\text { Senior } \\
(>65)\end{array}$ \\
\hline $\begin{array}{c}\text { Male } \\
(\mathrm{n}=74)\end{array}$ & 0 & 3 & 19 & 21 & 31 \\
$\begin{array}{c}\text { Female } \\
(\mathrm{n}=26)\end{array}$ & 2 & 5 & 8 & 7 & 4 \\
\hline $\begin{array}{c}\text { Total } \\
(\mathrm{n}=100)\end{array}$ & 2 & 8 & 27 & 28 & 35 \\
\hline
\end{tabular}

Based on age and sex categories, it illustrates the comparison between male CHD sufferers and female CHD sufferers in specific age categories. And we got the group of late adults, early elderly, and late elderly dominated by male sufferers. And only in the category of young adulthood (26-35) there are more female sufferers than men.

Table 3. Patient's personality type

\begin{tabular}{ccc}
\hline Personality type & $\begin{array}{c}\text { Frequency } \\
(\mathrm{n}=100)\end{array}$ & Percentage \\
\hline Conscientiousness & 50 & 50.0 \\
Neuroticsm & 22 & 22.0 \\
Agreeableness & 20 & 20.0 \\
Openness & 6 & 6.0 \\
Extraversion & 2 & 2.0 \\
\hline Total & 100 & 100.0 \\
\hline
\end{tabular}

Based on the theory of The Big Five Personality of Traits, there are five types of a person's personality, namely Conscientiousness, Neuroticism, Agreeableness, Openness, and Extraversion. From all patients with coronary heart disease data collected through the Big Five Personality questionnaire at the Dr. Soetomo General Hospital Surabaya, conscientiousness is the most common personality traits.

\section{DISCUSSION}

In this study, the data obtained based on the age group of patients, most of them were from the senior group (> 65 years) with $35 \%$. Studies conducted by Jousilahti and colleagues also prove the number of patients over 65 years had the highest number. This can be due to the increased risk of coronary heart disease in men and women because blood pressure and serum cholesterol also increase with age ${ }^{(\mathbf{8})}$.

Patients in this study were more dominated by male sex with $74 \%$, compared to the female sex, which was only $26 \%$. In a study conducted by Naveed Yazdani and colleagues, the number of comparison samples of coronary heart disease patients was $71 \%$ male and $29 \%$ female with a total sample of 176 people ${ }^{9}$. The comparison was also similar to the study conducted by Vaccarino $\mathrm{V}$ et. al. who said that the ratio of sufferers of 
coronary heart disease to men and women was $3: 1^{(9)}$. A higher men group can be caused by smoking, high total cholesterol, low HDL levels, high blood pressure, and higher BMI in men than women ${ }^{(\mathbf{8})}$.

$50 \%$ of the total patients in this study had a conscientiousness personality type. Then, $22 \%$ of the total patients had neuroticism personality type, $20 \%$ had agreeableness personality type, $6 \%$ had openness personality type, and $2 \%$ had extraversion personality type. Conscientiousness, Agreeableness, and neuroticism had a higher odds value on the relationship with coronary heart disease compared with other personality types ${ }^{(\mathbf{1 0})}$. However, the data above is different from the survey conducted by Jokela who explained that Conscientiousness was negatively correlated with the incidence of coronary heart disease ${ }^{(\mathbf{1 1})}$.

Conscientiousness personality types have a definite character to their health, and they will find out and apply something relevant to good health, so they tend to avoid the risk of coronary heart disease ${ }^{(\mathbf{1 2})}$. The difference between the above studies and this study can also be influenced by the presence of 2 types of Conscientiousness. Conscientiousness type can be distinguished into High Conscientiousness and Low Conscientiousness. High Conscientiousness correlates positively with adjustments to life's challenges and negatively correlates with smoking, substance abuse, and depression ${ }^{(\mathbf{1 3})}$. Low Conscientiousness has unorganized and unreliable behavior, and concentration is easily disturbed, and also has a relationship with health risk behaviors, such as smoking and drinking alcohol ${ }^{(\mathbf{1 2})}$. However, there are still other factors that can be significant risk factors for coronary heart disease besides personality factors, such as smoking and obesity conditions $^{(14)}$

\section{CONCLUSION}

Based on the results of the study, it can be concluded that conscientiousness was the most dominant personality type of patient with coronary heart disease in Cardiology's Outpatient Dr Soetomo General Hospital Surabaya in May 2019. From this study, we can increase our effort especially in preventive intervention for coronary heart disease, as we know this disease still be the majority cause of death in Indonesia. Furthermore, future studies with more patients of coronary heart disease are needed. Not only improvements from the amount of the sample study but also improvements for interventions based on the patient's dominant personality type in coronary heart disease.

\section{REFERENCE}

1. World Health Organization. Cardiovascular Diseases (CVDs). WHO; 2017. Available from: https://www.who.int/news-room/fact-sheets/detail/cardiovascular-diseases-(cvds).

2. MoH-RI. Heart Health Situation (Situasi Kesehatan Jantung). Jakarta: Pusdatin, MoH-RI; 2014. Available from: https://www.depkes.go.id/download.php?file=download/laporan/kinerja/lakip-kemenkes-2014.pdf.

3. Ambrose JA, Singh M. Pathophysiology of coronary artery disease leading to acute coronary syndromes. 2015;5(January):1-5.

4. Smeltzer S, Bare B. Surgical Medical Nursing Textbook: Brunner \& Suddarth (Buku Ajar Keperawatan Medikal Bedah: Brunner \& Suddarth). 8th ed. Jakarta: EGC; 2013.

5. Schneiderman N, Ironson G, Siegel SD. STRESS AND HEALTH: Psychological, Behavioral and Biological Determinants. 2005.

6. Dumitru VM, Cozman D. The relationship between stress and personality factors. 2010;4(1):34-9.

7. Goldberg LR, John OP, Kaiser H, Lanning K, Peabody D. An Alternative "Description of Personality": The Big-Five Factor Structure. 1990;59(6):1216-29.

8. Jousilahti P, Vartiainen E, Tuomilehto J, Puska P. Sex, Age, Cardiovascular Risk Factors, and Coronary Heart Disease. Circulation. 2012;99(9):1165-72.

9. Vaccarino V, Parsons L, Peterson ED, Rogers WJ, Kiefe CI, Canto J. Sex Differences in Mortality After Acute Myocardial Infarction. Arch Intern Med. 2009;169(19):1767-74.

10. Lee HB, Offidani E, Ziegelstein RC, Bienvenu OJ, Samuels J, Eaton WW, et al. Five-Factor Model Personality Traits as Predictors of Incident Coronary Heart Disease in the Community: A 10.5-Year Cohort Study Based on the Baltimore Epidemiologic Catchment Area Follow-Up Study. Psychosomatics. 2014;55(4):352-61.

11. Jokela M, Pulkki-Råback L, Elovainio M, Kivimäki M. Personality traits as risk factors for stroke and coronary heart disease mortality: pooled analysis of three cohort studies. J Behav Med. 2013;37(5):881-9.

12. Bogg T, Roberts BW. Conscientiousness and health-related behaviors: A meta-analysis of the leading behavioral contributors to mortality. Psychol Bull. 2004;130(6):887-919. 
13. Soldz S, Vaillant GE. The Big Five Personality Traits and the Life Course: A 45-Year Longitudinal Study Stephen Soldz and George E. Vaillant. 1999;232:1-25. Available from: https://univpn.univie.ac.at/+CSCO+0h756767633A2F2F6E702E7279662D7071612E70627A++/S009265 6699922432/1-s2.0-S0092656699922432-

main.pdf?_tid=3ad06c41fb3c599efca76d5e645d4352\&acdnat=1340816982_602aca67dbac1305e71245dc d527d129\%5Cnpapers3://publication/uuid/B63

14. Rachel Hajar. Risk Factors for Coronary Artery Disease: Historical Perspectives. Hear Views. 2017;18(2):109-14. 